\title{
BUILDING CONSENSUS ON EUROPEAN CONSENSUS
}

\author{
Conor Gearty
}

Before we can effectively build a consensus on European consensus, we first need to be clear about why it matters. As Sionaidh Douglas-Scott reminds us, 'a consensus is a widespread or generally accepted opinion or decision among a group' ${ }^{1}$ - not the same as unanimity; indeed, it even allows some members of the community to dislike the decision or opinion which is the subject matter of the agreement. Furthermore, Douglas-Scott goes on, 'whereas in contemporary usage, 'consent' connotes a positive act - an explicit act of agreement, an active act - consensus instead has taken on the form of 'a passive acquiescence to an act.",2 At first and perhaps even second glance, should the whole notion of seeking consensus surely lie outside our interest? We are discussing a European multi-state agreement, the European Convention on Human Rights (ECHR), which, on its own description, is devoted to the protection of 'human rights and fundamental freedoms'. Now, it would be fair to say that these are not guarantees that those unversed in the complexities of human rights law are inclined to dilute by reference to any kind of consensus at all. Far from it: to the layperson, the terms 'human rights' and 'fundamental freedoms' stand as benchmarks of ethical certainty in a deeply relativistic political world, a set of values realised in specific rights and obligations that we precisely do not relinquish even while the exigencies of the majoritarian present batter out of recognition all the other truths that swirl around us. They are our lighthouse, beaming dependable truth in our stormy political sea, guiding our life journey to safe harbour. Or so the well-disposed general public believe (often, if truth be told, with our connivance). ${ }^{3}$

And to push this metaphor perhaps just one step too far, the activists for our subject are in exactly the same boat. These human rights warriors and human rights missionaries criss-cross the seas on a perpetual search for a better world for the vulnerable, the oppressed, those millions for whom even the chance to have life chances is a forlorn dream. The job of these admirable crusaders is to impose their moral vision of equality and universal dignity on those - the powerful; the elites - who stand in their way. There is no time for 'reaching out' - for building agreement, conceding this to get that. The lighthouse says where to go; tacking to the right or left is an unnecessary deviation. Indeed, even within academe, the notion that consensus matters to what human rights are would, in many quarters, be greeted with surprise. Our international relations and political science colleagues may be quick to see 'human rights' as a move in a game (to consolidate Western power after the Second World War; to protect minority communities in a newly independent state; to entrench the status quo against radical change), but the power of such observations lies precisely in the assumption that such rights can stand outside the moment, imposing themselves on the day's consensus rather than being slaves to it. ${ }^{4}$ Even when the philosophers come along and redefine

\footnotetext{
${ }^{1}$ See the chapter by S. Douglas-Scott, sec. 2.

${ }^{2}$ See the chapter by S. Douglas-Scott, sec. 2.

${ }^{3}$ See the excellent F.M. Klug, Values for a Godless Age (London: Penguin, 2000) and her more recent A Magna Carta for All Humanity. Homing in on Human Rights (Abingdon: Routledge, 2015).

${ }^{4}$ J. Donnelly, Universal Human Rights in Theory and Practice, 3rd edn (Ithaca: Cornell University Press, 2013).
} 
democracy to incorporate rights protection (so that the idea that the majority rules becomes something crude and different, called 'majoritarianism'), their main reason for doing so is to keep rights apart from the crowd, always looking down on the rabble, not (as consensus seems to suggest) floating even half way up from the chaos of the unprincipled, unreflective noise below. ${ }^{5}$

We lawyers, especially we human rights lawyers, know better. The many chapters here which precede this afterword bear testimony to that. When human rights take serious legal shape, it is time to set aside the philosopher's cloak and the ethical bully pulpit. No document takes human rights more seriously than the ECHR, the centrepiece of our discussions in this volume. While it is perfectly true, as Lucas Lixinski reminds us, that consensus is not a compulsory feature of regional human rights adjudication, ${ }^{6}$ it is embedded within the document and case law that are our focus here. Thus, and contrary to the assumptions of those outside our field, before we even get to the cases (which will be discussed further below), the very text and structure of the ECHR bear the strong imprint of the series of political agreements that made it possible: For Christian Djeffal, it 'can be argued that the ECHR itself is a form of consensus'. ${ }^{7}$ Indeed, removing the equivocation from this, it is not going too far to say that the Convention was first forged and then preserved by consensus. The preamble reminds us of the 'common heritage of political traditions, ideals, freedom and the rule of law' without which the ECHR would have been impossible. There is the shared agreement between the contracting states, not only on rights, but also on when they can be flouted, the 'necessities in $a$ (not the) democratic society' that permit the departure from rights by reference to an abstract idea of what a democratic state is, one that is then indirectly fleshed out in provisions like those on emergencies (Article 15) and the abuse of rights (Article 17). The opportunity for signatory states to make reservations to its commitments under the Convention (Article 57) may be commonplace in international law, but in being so, it is a reminder that agreements such as this stand or fall on the state support they secure across the board. States can also renounce it if they choose (Article 58).

This conditional quality is also to be found in its mode of implementation- the European Court of Human Rights (ECtHR) has not been given any shock troops to impose its will; rather, it has to rely on the state party itself to do its enforcement work, overseen by a Committee of Ministers whose membership receives training, much of which is focused in the field of consensus-building, not moral imposition. Where a state appears to be ignoring a judgment, two-thirds of the Committee will be needed to send the matter back to the Court (Article 46(4)), a very real intrusion of the diplomatic into the implementation of a European Court's pronouncements that the unversed take to be definitive.

This afterword to the excellent series of papers that make up this collection offers a short reflection on what has gone before and - building on this - develops a robust defence of its

\footnotetext{
${ }^{5}$ Of many authors, see most prominently R. Dworkin, Taking Rights Seriously (London: Duckworth, 1997).

${ }^{6}$ See the chapter by L. Lixinski.

${ }^{7}$ See the chapter by C. Djeffal, sec. 2.3. M. Duranti, The Conservative Human Rights Revolution. European Identity, Transnational Politics, and the Origins of the European Convention (Oxford: Oxford University Press, 2017) is now the key text on the document's drafting.
} 
subject matter. Consensus is what has made our Convention possible and what keeps its show on the road. Without it, this brand of human rights law would not have lasted a week in the world in which we actually happen to find ourselves, as opposed to that of our imagining or our dreams. Of course, it has its problematic aspects, and these we need to negotiate in order to keep the ECHR on track. Stimulated by what has gone before, this is what this concluding essay seeks to do.

Take as a start and by way of preliminary evidence the exhibits mustered by Ed Bates in the course of his careful study of the early life of the Convention. ${ }^{8}$ Bates's essay reminds us of how deeply embedded the drive for consensus is within the Convention system: how it extends beyond the textual evidence to imprint its assumptions on the way the scheme has operated. However carefully it was negotiated, state support for the Strasbourg organs did not flow automatically upon their creation, but had to be hewn out of practice, in what Bates calls the ' 'legitimacy-building' phase' of the Convention's life. ${ }^{9}$ This Bates places at 'the almost half-century period from 1950, when the Convention was opened for signature, until 1998, when Protocol 11 entered into force'. ${ }^{10}$ He reminds us of the occasional use that was made of 'comparative surveys of the national law of the Convention States' as early as the mid- to late 1960s, and of the emphasis on the search for common legal traditions that was evident in the articles written and speeches given by Commissioners and judges during this period. ${ }^{11}$ Then, there are, of course, the Strasbourg decisions themselves. Citing Wildhaber, Hjartarson and Donnelly, Douglas-Scott reminds us of the 'three pioneering cases Tyrer, Marckx and Dudgeon, decided around 1980, [which together] constitute the first examples of consensus analysis in the history of the ECtHR. ${ }^{12}$ In even that high point of Strasbourgian assertiveness, with human rights being given their full head, the trick was often to find an emerging consensus and use it to bring the laggards into line. Dimitrios Kagiaros's essay on the impact of consensus in the field of minority rights shows us how the Court was able intelligently to deploy the language of consensus and trends so as to avoid accusations of going beyond its original remit - something of particular importance when (as in this field) Convention rights are being given an innovative cutting-edge in (as Kagiaros calls them) these 'novel' areas. ${ }^{13}$ Controversial though some of the broader juristic experiments of the ECtHR might have been, the pay-off for the Court's acknowledgement of the value of consensus was that by the 1990s (to quote Bates again), the Strasbourg institutions 'managed to build up a large credit in their favour, securing political consensus as to their role, ${ }^{14}$ Early suspicions of the system as a 'threat to ... sovereignty' ${ }^{15}$ had largely fallen away. Bates's

\footnotetext{
${ }^{8}$ See the chapter by E. Bates.

${ }^{9}$ See the chapter by E. Bates, sec. 1.

${ }^{10}$ See the chapter by E. Bates, sec. 1.

${ }^{11}$ See the chapter by E. Bates, sec. 2.1.

12 See the chapter by S. Douglas-Scott, sec. 3. L. Wildhaber, A. Hjartarson and S. Donnelly, 'No consensus on consensus? The practice of the European Court of Human Rights’ (2013) 33 Human Rights Law Journal 248.

${ }^{13}$ See the chapter by D. Kagiaros, sec. 1.

${ }^{14}$ See the chapter by E. Bates, sec. 1.

${ }^{15}$ See the chapter by E. Bates, sec. 1.
} 
strong position, surely correct, is that consensus was essential to this right from the start, 'an important, indeed necessary feature of the success story' that would follow. ${ }^{16}$

The Strasbourg court never lets this out of its mind, even if the price is on occasion (and Merris Amos's essay makes this point strongly so far as recent cases involving the United Kingdom - surprisingly deferential - are concerned ${ }^{17}$ ) to be deemed irresolute, unduly passive or lacking in conviction. Consider for a moment what might happen were this caution now to be cast aside or (even worse) to have been thrown to the wind from the start. We do not need to speculate: We have three pieces of direct evidence, two from the United States and one from Ireland. The first is the 'colossal blunder' (as lawyer and historian of the Supreme Court Archibald Cox called it) of Dred Scott v. Sandford in $1857 .{ }^{18}$ That famous critic of human rights, the utilitarian Jeremy Bentham, wrote of the dangerous capacity for violence in the language of rights, in which, as he put it, 'an improper word may be a national calamity:- and civil war may be the consequence of it. Out of one foolish word may start a thousand daggers. ${ }^{19}$ But even he could hardly have predicted that a ham-fisted effort to close down the politics of race in 1850s America - by declaring that a black man was property within the meaning of the fifth amendment and so could not be taken from his or her slave owner 'without due process of law' - would play a large part in producing exactly this outcome. Or, to flash forward to 1973, there is that well-known (and this time liberal) intervention by a majority of Supreme Court justices in the abortion rights case Roe v. Wade, the effect of which was to propel America further into, not away from, the cultural wars which have since then so affected that country's political and legal discourse. ${ }^{20}$ And finally, Ireland, where a constitutional amendment believed to be definitive on the protection of the rights of the unborn turned out, in practice, to be the opposite. ${ }^{21}$ All these interventions, two judicial and one via a referendum, eschewed consensus in the name of an absolutism that the very language of human rights seems to invite, with, in each case (I would argue), drastic consequences for the polity, people and culture. ${ }^{22}$ Nor are they alarmist examples to parade in front of a cohort of human rights scholars wishing they could do more; they are warnings about the real danger that every moment of unexpected victory brings, of the price of getting ahead of or disregarding the politics of the day, even if the law behind it seems clear to those making the decision.

If we may confidently conclude that so far as the ECHR is concerned, consensus is essential, we must also acknowledge - as the Court generally does - that it is also dangerous. While the absence of consensus risks chaos, too much of it is a sure recipe for superfluity. Had the Supreme Court in Washington retreated totally into its shell after the mistaken absolutism of Dred Scott and Roe (and there are, of course, other examples), much progressive work would not have been achieved, not least in the period of the Warren Court, of course, but also (more

\footnotetext{
${ }^{16}$ See the chapter by E. Bates, sec. 1.

${ }^{17}$ See the chapter by M. Amos.

${ }^{18} 60$ US 393 (1857). A. Cox, The Court and the Constitution (Boston: Houghton Mifflin, 1987).

19 The whole polemic is well worth reading: see J. Waldron (ed.), Nonsense Upon Stilts. Bentham, Burke and Marx on the Rights of Man (Abingdon: Routledge, 2015; first published Methuen, 1987), chapter 3.

${ }^{20} 410$ US 113 (1973).

${ }^{21}$ Eighth Amendment to the Constitution 1983.

${ }^{22}$ C.A. Gearty, 'The politics of abortion' (1992) 19(4) Journal of Law and Society 441-53.
} 
recently) through the June 2015 decision to characterise gay marriage as a constitutional right, Obergefell v. Hodges. ${ }^{23}$ The Strasbourg judges are duty bound to be as alive to the dangers of too much consensus as they are to the risk of not looking for it; the threat overdependence on it presents to what Helen Fenwick, in a recent article, called the Court's 'normative legitimacy'. ${ }^{24}$ Who wants our rights to be determined by some sort of supreme EURORIGHTS CONTEST, with litigants reliant on the support they can garner from as many of the 47 participating nations as possible, thus turning the Court into the keeper of a tally of the rights of others, rather than an adjudicative body in its own right?

So, to ask a classic Strasbourg question, how is it possible for the ECtHR to get the balance right? Now, this is the point at which it might be thought tempting to return to the cases just referred to and castigate them for departing from the plain words of the ECHR so as to contrive a contemporary consensus that cannot survive a critical examination informed by that text. However, and regardless of the coherence of the creative approach favoured by the more progressive cases (which will be addressed more fully presently), it is surely no answer to say that the remit of the rights set out in the Convention is clear, that the consensus about the need for such a set of rights (reflected in the text - consensus achieved at a high order of abstraction) also extends to the substance of the rights themselves at the time of their drafting, and that we can therefore stop our search for consensus simply by reading the agreed text from 1950 and putting the words found there into practice. The range and complexity of the themes rehearsed in this volume is testimony to how clearly this is not an approach that has been followed. That said, it is certainly true that so far as those few rights of textual simplicity that have continued to attract universal unqualified acceptance since their agreement in 1950 are concerned, the ECtHR is often emboldened to set aside any search for consensus en route to decisive action in the name of such rights. It is in choosing such direct routes that the ECtHR can be seen doing its best ethical work: the Polish authorities required to pay compensation for US black sites; ${ }^{25}$ the refusal to send Abu Qatada to a trial in Jordan tainted by torture evidence; ${ }^{26}$ the clamping down on brutal action overseas by the military forces of Member States; ${ }^{27}$ and so on. But even on the margins of these absolutes, there are grey areas, about how far to push these rights (the limits of torture ${ }^{28}$; the extent of inhuman and degrading treatment; the range of servitude and forced labour; as the examples just given demonstrate, the breadth of jurisdictional reach?). The belief that as Jaroslav Vertrovský puts it 'a concept applies to the various things that fall under it by virtue of their essential characteristics' begs a great number of questions when transferred to the legal arena. ${ }^{29}$ Even in such environments of ethical clarity as are presented by the unqualified rights' claims in the Convention, there are these inevitable uncertainties, and where guidance is wanting, the lure of consensus can always be found on the side-lines, offering redemption. And if this is

\footnotetext{
${ }^{23} 576$ US _ (2015).

${ }^{24}$ H. Fenwick, 'Same-sex unions at the Strasbourg Court in a divided Europe: driving forward reform to protecting the Court's authority via consensus analysis?' (2016) 3 European Human Rights Law Review 249-72.

${ }^{25}$ Al Nashiri v. Poland (Appl. no. 28761), Judgment, 24 July 2014.

${ }^{26}$ Othman (Abu Qatada) v. United Kingdom (Appl. no. 8139/09), Judgment, 17 January 2012.

${ }^{27}$ Al Skeini v. United Kingdom (Appl. no. 57721/07), Judgment, 7 July 2011.

${ }^{28}$ Ireland $v$ United Kingdom 20 March 2018.

${ }^{29}$ See the chapter by J. Větrovský, sec. 2.
} 
true of the straightforward Articles 3 and 4, how much more is it of the rest, whose caveats and uncertainties are much clearer on their face? Where Articles 8, 9, 14 and so on are concerned, the grey areas rush ever more quickly to the fore, with consensus much more likely therefore to play a role in the resolution of their meaning on a case-by-case basis as a result. 'Text matters', ${ }^{30}$ but not exclusively so.

At this point, another potentially simple route to our question about balance needs to be identified so as also to be rejected: if the substance of the rights is not clear on its face on the whole, and if, as a result, we need to rely on consensus that goes beyond the words used as a key tool in giving them meaning, then why not set that inquiry at the moment of the ECHR's formulation rather than find ourselves endlessly fastening on later dates in an inevitably rather arbitrary and ever-changing fashion -? On this analysis, consensus would continue to matter, but it would be the consensus of 1950/1953 that we would need to discover, not that of today. The words in the ECHR may not give us the answers, but the backstory to the text and the accompanying contemporary evidence of its meaning would. A happy consequence of this would be a permanent resolution of the concerns about the legitimacy of judicial action which, to some degree, the case-law on consensus has been developed to address: guarding against any overreach in the name of normative obligation. A theory of rights' interpretation was invented in the United States in order to give intellectual cover to just such a position - the doctrine of original intent - and it has enjoyed something of a resurgence of popularity in some parts of Europe, not least in the United Kingdom, where some grand judicial figures have taken it up. ${ }^{31}$ How and why the idea took hold in the US may be an American story, but it tells us something important about Europe as well, and about why the Court has been right not to go down this route.

The wheeze of insisting federal courts restrict themselves to what the drafters of the US bill of rights at the end of the $18^{\text {th }}$ century thought they were doing was popularised by President Reagan's Attorney General Ed Meese. ${ }^{32}$ The plan was to unravel Roe v. Wade - whatever Jefferson and later post-civil war drafters were thinking about when they came up with the US bill of rights and its mid- $19^{\text {th }}$ century amendments, it was not abortion. The wider hope was to roll back the progressive inclinations of a Court that had been engaged in expansive interpretations of these constitutional rights since the mid-1950s. (The famous Brown v. Board of Education decision of 1954 on school desegregation ${ }^{33}$ is the most convenient starting point). That this movement did not succeed can be seen from the aforementioned Obergefell v. Hodges: the founding fathers of America may not have been feminists, but they definitely were not gay rights activists. While the approach may be on the wane, it has had a huge impact on the Supreme Court in that jurisdiction, particularly on the process by which new justices get affirmed before the Senate. And in American academe, it has thrown a new

\footnotetext{
${ }^{30}$ K. O’Regan, 'Text matters. Some reflections on the forging of a new constitutional jurisprudence in South Africa’ (2012) 75(1) Modern Law Review 1-32.

31 Jonathan Sumption, QC, 'Judicial and political decision-making: the uncertain boundary', The F A Mann lecture 2011, www.pem.cam.ac.uk/wp-content/uploads/2012/07/1C-Sumption-article.pdf (accessed 11 October 2017). Shortly after this lecture, Lord Sumption took up a position on the UK Supreme Court.

32 Speech to the American Bar Association 9 July 1985: www.justice.gov/sites/default/files/ag/legacy/2011/08/23/07-09-1985.pdf (accessed 11 October 2017)

33347 US 483 (1954).
} 
emphasis on recherché aspects of late $18^{\text {th }}$ century law that has at times seemed entirely bizarre.

So what is there to learn from this? The doctrine of original intent was thought to be needed, not to protect that original intention from destruction (not an issue in America where, even with the incumbent president, the basics of the constitution are revered), but to inhibit the Court from putting grander flesh on the bare bones of the civil rights to be found in its foundational instrument, a document about which crucially there was now no argument about their right to interpret: Marbury v. Madison from $1803^{34}$ had settled the point, and not even the most extreme of the original intent activists wanted to dredge this one up. ${ }^{35}$ The original intent doctrine was doomed to failure because it seems to demand of the Supreme Court justices that they give up all expansionary possibilities in favour of a determined commitment to looking backwards. This is a big ask of any judge, regardless of his or her political sympathies. Forward is more fun; backward is - well - more backward. There is not much to do on a bench when you are constitutionally committed to thinking only about yesterday; in a choice between growing (the rights) or dying (of neglect), it will be a very hardy original intentor that will choose the second.

The Strasbourg Court faced the same predicament, in a not dissimilar context. It is patently clear that the drafters agreed that they were constructing a floor of abstract basic rights below which European polities could not be permitted to go. By our standards today, the discoverable consensus of the early 1950s about what that floor was composed of seems pretty unambitious, fairly rudimentary in fact. But not to the drafters at the time: the fundamental rights that were the mainstay of the liberal democracies that were then being constructed in Europe looked as fragile as they were appealing. Why else go to the trouble of creating a European Commission on Human Rights and (eventually) a European Court of Human Rights if you did not think that the floor you were constructing was altogether more insecure than the grand language in your agreed document made it seem? ${ }^{36}$ The ECtHR was to be an important guarantor of the floor, unlocked through the Inter-State application process (that was the main litigation route we should recall) when all else seemed to be failing.

Now wonderfully, just as in the United States, the European Court of Human Rights has not, on the whole (there have been exceptions, of course, and there may be more to come - I shall come back to this), found itself having to deploy itself as the original drafters feared it might, i.e. as a defensive shield against lurches away from democracy. The experiment of European state-building has been such a success that the defensive power of the ECtHR has not had to be mustered. So, had the Convention been left as Bates puts it as (merely) 'a type of collective pact against the re-emergence of totalitarianism in Europe', ${ }^{37}$ it would surely have been condemned to near obscurity and played very little role in the development of post-War Europe. This cannot mean that the Court ceases to be, or that it is duty-bound simply to

\footnotetext{
345 US (1 Cranch) 137 (1803).

35 Even the combative Robert Bork: R.H. Bork, The Tempting of America. The Political Seduction of Law (London: Sinclair-Stevenson, 1990), pp. 22-24, 145.

${ }^{36}$ See generally Duranti, The Conservative Human Rights Revolution: European Identity, Transnational Politics, and the Origins of the European Convention (New York: OUP, 2017).

${ }^{37}$ See the chapter by E. Bates, sec. 1.
} 
withdraw honourably from the fray, with a departing message along the lines of 'call us when you are in real trouble' - yet such would have been the effect of reverting to original intent. Far from it. The Court has faced the same challenge as that confronted by the US Supreme Court, and it too has chosen growth. Thomas Kleinlein puts it well in his essay: 'Europe has changed considerably since the late 1940s and early 1950s, when the Convention was drafted. If the Convention is to serve as a meaningful instrument of rights protection today, the Court must reflect these changes by means of evolutive interpretation. Therefore, the relevance of the State Parties' original consent for the Court's legitimacy is necessarily limited' ${ }^{38}$

That the ECtHR has made a success of the broader mission it has embraced can be seen from Bates's remark about the legitimacy it has achieved with which we began this enquiry. This can also be seen both from the greater responsibilities that have been heaped upon it (individual applications; new signatory states; the abolition of the Commission) and the exponential increase in the cases before it, even while - in these days of liberal democratic hegemony - its original mission has been something which, gratifyingly, we have largely (so far) been able to take for granted. And if the primary explanation for the expanded Convention-canvass on which the Strasbourg judges have chosen to draw is this well-known idea of the Convention as 'a living instrument', ${ }^{39}$ then a dynamic, evolving consensus has been the midwife giving birth to these new, expanded rights. Not only has it helped to induce them, but it has also been the post-natal and wet nurse, hovering concernedly in the background until they can stand on their own two feet. The highlights of this story are wellknown and were already briefly mentioned at the start. As early as 1978, the Court was seeing off one kind of consensus, a wholly local one, namely that people on the Isle of Man were quite up for a bit of judicial corporal punishment, with this other European one:

The Court must also recall that the Convention is a living instrument which, as the Commission rightly stressed, must be interpreted in the light of present day conditions. In the case now before it the Court cannot but be influenced by the developments and commonly accepted standards in the penal policy of the member states of the Council of Europe in this field. ${ }^{40}$

In Dudgeon v. United Kingdom a few years later, another sub-state practice, Northern Ireland's laws against homosexuality, were given short shrift on the same basis. ${ }^{41}$ Not even a 'local practice' extending to the whole of a member State can protect it from the interventionist power of a European Court of Human Rights whose 'living instrument' is, on the issue before it, informed by the controverted practice being rejected by many states, as Ireland and Cyprus found to their cost, when their country-wide bans on homosexual practices fell afoul of the Court's reading of the Convention's right to privacy: ${ }^{42}$ And in this

\footnotetext{
${ }^{38}$ See the chapter by T. Kleinlein, sec. 2.1.

${ }^{39}$ See G. Letsas, 'The ECHR as a living instrument: its meaning and legitimacy', in A. Føllesdal, B. Peters and G. Ulfstein (eds.), Constituting Europe. The European Court of Human Rights in a National, European and Global Context (Cambridge: Cambridge University Press, 2013), chapter 4.

${ }^{40}$ Tyrer v. The United Kingdom (Appl. no. 5856/72), Judgment, 25 April 1978, para. 31.

${ }^{41}$ Dudgeon v. United Kingdom (Appl. no. 7525/76), Judgment, 22 October 1981, para .60.

${ }^{42}$ Norris v. Ireland (Appl. no. 10581/83), Judgment, 26 October 1988; Modinos v. Cyprus (Appl. no. 15070/89), Judgment, 22 April 1993.
} 
context we should note too Fiona de Londras' chapter, with its scathing critique of reliance on referenda as a driver of respect for national autonomy. ${ }^{43}$ As this volume illustrates, similar stories can be told of the achievement of other changes under the same 'living instrument' umbrella, on corporal punishment in schools and the home, and on the protection of transsexuals. Sometimes, it is a consensus to which the Court can confidently point; sometimes, it is, more ambitiously, 'an emerging consensus' - the birth needs to be induced, helped on its way by a judicial midwife that is certain of its importance.

So, to return to my earlier question, if text and original intent are no good, and if consensus is instead to be a dynamic idea, how has this been done, and in achieving it, has the 'right' balance between normativity and deference been achieved? It is surely clear that at the core of consensus must lie an initial view held by members of the Court itself engaging with an issue about the need for this or that development of a right, and (if that need is there) about the extent to which it is proper to push a European-wide meaning of the right (if one is available) on a recalcitrant state. Another way of putting this might be that the judges must look first for normative guidance (need) and then for persuasive realisation (consensus). At the beginning of his essay, Or Bassok sets out well the reasons why consensus is so attractive to a Court in a creative mode: '.. it leads to better results in terms of the quality of judgments; ... it makes these judgments more normatively justified; ... it offers a good way to persuade the ECtHR's constituency. ${ }^{44}$ Furthermore, Bassok argues, by dissolving 'any threat to public confidence in the ECtHR', the consensus doctrine is, valuably, a tool to ensure the ECtHR's 'sociological legitimacy' in the sense that, in using it, the Court 'minimises the chances of losing public confidence because it does not counter public opinion. 45

The challenge to normativity that consensus presents cannot, however, be as easily discounted as this. We see this in the deployment by Douglas-Scott of two heavyweight judicial figures, first former Judge MacDonald, who argues that by using this approach, the Court 'forfeit[s] its aspirational role by tying itself to a crude, positivist conception of "standards" [. . .] and prevents the emergence of a coherent vision of the Court's function, ${ }^{46}$ and also in the remarks of former ECJ judge John Murray to the effect that the 'use of consensus as an interpretative tool is inherently problematic, not only because of any perceived inconsistency in the application of the doctrine by the Court, but fundamentally because the very application of a doctrine of consensus by a court required to adjudicate on fundamental rights begs important questions of legitimacy. ${ }^{47}$ The judges do not like being fastened down to the democratic present - it is as bad to be tied to the present as it is to original intent.

\footnotetext{
${ }^{43}$ See the chapter by F. de Londras.

${ }^{44}$ See the chapter by O. Bassok, sec. 3.

${ }^{45}$ See the chapter by O. Bassok, sec. 3.

${ }^{46}$ See the reference made to Judge MacDonald in the chapter by S. Douglas-Scott, sec. 5 .

47 John L. Murray, 'Consensus: concordance, or hegemony of the majority?', in Dialogue Between Judges (European Court of Human Rights, Council of Europe, 2008): www.echr.coe.int/Documents/Dialogue_2008_ENG.pdf (accessed 12 October 2017).
} 
Now, wading further into the ECtHR's actual practice, and as earlier anticipated, we are forced to enter difficult territory. How rigorous has the search for consensus been? Critics argue about the selectivity of the database on which the 'consensus/emerging consensus' argument depends, and this is reflected in the contributions to this volume. For DouglasScott, what is concerning are the many weaknesses that are to be found in the 'methodology and procedure in the application of the consensus criterion', concerning

the nature of the comparative process itself, a vexed issue in comparative law. For example, what is it that is to be compared in order to determine if a consensus exists? At what level of abstraction must this be undertaken? ... Is the determination of a consensus more important in some areas than others? It seems that the concept of consensus has been more frequently used in Article 8 ECHR and personal autonomy cases, but why should this be the case? And once the comparison is undertaken, how is the existence of a consensus determined? How much similarity in how many countries will establish a consensus? ${ }^{48}$

A related worry for Christian Djeffal is the 'question of whether to choose a wider or narrower sample' which - inevitably 'has an important impact on the actual numbers' driving the finding on consensus. ${ }^{49}$ This is because, as he remarks, 'the choice of a sample can substantially influence the result'. ${ }^{50}$ To Merris Amos, there is a risk of consensus being deployed as a defensive shield to protect states from a rights' activism that might produce a dangerous counter-reaction: Unsurprisingly, her concerns emerge in the context of a close study of the ECtHR's recent rulings concerning the United Kingdom. ${ }^{51}$ Niamh Nic Suibhne begins her chapter with the salutary tale of Netherlands v. Reed, in which the ECJ was able to deliver a progressive outcome 'by attaching its legal solution to the general principle of equal treatment', ${ }^{52}$ something on which all Member States could be said to agree, rather than on the tricky issue of the treatment of unmarried partners, on which states were by no means unanimous. We can see from this that the choice of what to look for consensus over can sometimes itself be very loaded. Jens Theilen's account of the comparative reasoning of the European Court of Justice and the European Court of Human Rights reveals how the former tends 'towards more general comparative references', while the latter is inclined to be 'more specific and thus more sensitive to difference'. ${ }^{53}$ There is a vital series of critical points coming through in these essays about the choice of the level of abstraction at which the search for consensus is operated, about how that choice influences outcomes, and about how settling upon the sample or the reach of the enquiry can easily predetermine the outcome.

And, allowing these insights to push us even further into scepticism, can we avoid that lurking thought that consensus is not a rational mode of analysis at all, but rather just another tool with which to deliver an outcome intuited as desirable in any given case? Laura Van den Eynde's trawl through the amicus curiae briefs filed before the Grand Chamber between

\footnotetext{
${ }^{48}$ See the chapter by S. Douglas-Scott, sec. 5 .

${ }^{49}$ See the chapter by C. Djeffal, sec. 4.3.

${ }^{50}$ See the chapter by C. Djeffal, sec. 4.3.

${ }^{51}$ See the chapter by M. Amos.

52 See the chapter by N.N. Shuibhne, sec. 1.

${ }^{53}$ See the chapter by J. Theilen, sec. 5 .
} 
1994 and 2015 is fascinating for its account of the progressive development of the Convention via the deployment of what she describes as the 'creatively used majoritarian argument'. ${ }^{54}$ What seems to be going on here is that in their entirely understandable desire to achieve the change for which they are litigating, the non-governmental organisations do not, as Van den Eynde politely puts it, 'feel constrained by rigid standards ... to demonstrate ... consensus'. Rather, they 'refer to consensus and trends, but define them creatively'. ${ }^{55}$ So much of the progress in the 'Golden Age' of the mid years of the Court's jurisprudence, the Tyrer's, Dudgeon's and so on, reflected engagement of this sort, as was reflected also in Amnesty International's intervention in Soering, ${ }^{56}$ for example, and that of Liberty in Goodwin v. United Kingdom. ${ }^{57}$ Dimitrios Kagiaros shows how what he describes as 'an emerging international consensus' has also been an important driver requiring states to be vigilant in the protection of the rights of minorities. ${ }^{58}$ Member states may be able to deliver a compelling consensus argument for innovation, but if that is not possible, there is always the rest of the world to plunder for good examples - fixing the reach as it was put in the last paragraph. Van den Eynde's close reading of the scores of relevant amicus curiae briefs leads her to express disappointment that 'no clearly expressed justification as to the relevance of the consensus argument was found in the briefs'. ${ }^{59}$ The author calls 'for greater transparency, methodological rigorousness and absence of selection bias regarding the collection of comparative data and the choosing of countries - particularly when countries outside the Council of Europe are cited' ${ }^{60}$ While this makes clear sense for the scholar and perhaps also the judge, why should an NGO (or a passionate judge) risk sacrificing a desired outcome at the altar of intellectual consistency? Campaigners have no obligation to be even-handed and an inclination not to be dispassionate. It is for the ECtHR to impose order - but what if order inhibits its judges from making the moral progress they desire?

At this juncture, the often under-noticed nature of the ECtHR itself needs to be mapped into the discussion. This emerges in the course of Jaka Kukavica's compelling analysis of the way the $8^{\text {th }}$ amendment to the US Constitution has been interpreted. ${ }^{61}$ Kukavica's review of the case-law reveals a high level of American Supreme Court consistency, with litigants able to say confidently what is expected of them if they are to win their case on this argument (essentially, national consensus is not enough, with lack of proportionality also having to be proved). The contrast with the ECtHR is marked: its applicants 'have not had the privilege of anticipating whether demonstrating European consensus would automatically bring the judgment in their favour. Nor have they been able to foresee which indicia to argue to demonstrate an existing consensus to the same extent as litigants before the Supreme Court. ${ }^{62}$ Reflecting on the lessons learnt, Kukavica highlights the structural obstacles that lie in the way of a coherent framing of consensus by the Strasbourg Court: the vast docket

\footnotetext{
${ }^{54}$ See the chapter by V. den Eynde.

${ }^{55}$ See the chapter by V. den Eynde, sec. 2.

${ }^{56}$ Soering v. United Kingdom (Appl. no. 14038/88), Judgment, 07 July 1989.

${ }^{57}$ Christine Goodwin v. The United Kingdom (Appl. no. 28957/95), Judgment, 11 July 2002.

${ }^{58}$ See the chapter by D. Kagiaros, sec. 3.1 (emphasis added).

${ }^{59}$ See the chapter by V. den Eynde, sec. 6.

${ }^{60}$ See the chapter by V. den Eynde, sec. 6.

${ }^{61}$ See the chapter by J. Kukavica.

${ }^{62}$ See the chapter by J. Kukavica, sec. 3.3.
} 
suffocating judicial creativity ('With 45,576 cases decided in 2015, an average ECtHR judge decided 970 cases in a year, amounting to, on average, 2.7 cases per day! ${ }^{63}$ ]; the large number of judges militating against the emergence of a shared view on any kind of consistent basis ('it is sometimes hard to reconcile ... the ideological, political, and legal views of fortyseven individuals, each of whom was educated and legally and professionally matured in a different legal system, some of them in a different legal tradition or even a different economic and political system, ${ }^{64}$ ); the 'linguistic barriers inherent in the fact that a vast majority of the judges are required to communicate and work in their second or even third language'; ${ }^{65}$ and finally, but perhaps most dramatically, the court as such (in the sense of the 47 judges) never gets to sit together as a single bench ('Obviously, the fact that an average judge, in three years, never sits on the bench with a staggering eighty per cent of judges that comprise the Court makes it extremely unlikely for the Court to come up with a consistent conceptualisation of European consensus. ${ }^{66}$ ).

If we are determined to argue that consensus is essential, what kind of future for it can be laid out which defends it against the range of criticisms mustered in this volume (some rehearsed here just now, with more to be found scattered across the chapters of this book)? How do we avoid the deliberately crude conclusion that the ECtHR needs a dynamic approach to consensus, one not stuck in the early 1950s, but that its organisational structure and its caselaw show a body condemned to handling it badly? This is to give up too easily: it is surely not the case that unsatisfactory treatment of its interpretive concepts - of which consensus is one - must be regarded as inevitable. Van Den Eynde is not wrong to call for a more transparent approach, even if the NGOs and the judges might occasionally benefit from obscurity. And, in a similar vein, Kristin Henrard is absolutely right that 'it is essential for a transparent and consistent methodology to be developed by the Court on how it ascertains the strength of' any given supposed European consensus. ${ }^{67}$ For all its philosophical beauty, the settling for an approach rooted in Wittgenstein's 'family resemblances concept', for which Jaroslav Větrovský imaginatively argues, may not be enough in the circumstances. ${ }^{68}$ The beginnings of the search for a solution lie in co-ordinating the approach to consensus with that taken to others of the Court's guiding abstract concepts. To take perhaps the central example, if, as Douglas-Scott puts it, '[m]argin of appreciation and consensus are the yin and yang of the European Court's jurisprudence ${ }^{69}$ so far as fleshing out the ECHR's potential for growth is concerned, how can these twins be managed in a way that allows the case-law to give meaning to Strasbourg's oversight, while not unnecessarily inflaming negative domestic reaction?

Thomas Kleinlein's view is that the answer lies in that old lawyers' standby, due process and just because something is 'old hat' does not mean that it is not a good fit. In his

\footnotetext{
${ }^{63}$ See the chapter by J. Kukavica, sec. 4.

${ }^{64}$ See the chapter by J. Kukavica, sec. 4.

${ }^{65}$ See the chapter by J. Kukavica, sec. 4.

${ }^{66}$ See the chapter by J. Kukavica, sec. 4.

${ }^{67}$ See the chapter by K. Henrard, sec. 5.2.

${ }^{68}$ See the chapter by J. Větrovský.

${ }^{69}$ See the chapter by S. Douglas-Scott, sec. 3.
} 
compelling essay on 'Constructive Consensus and Domestic Democracy', Kleinlein argues that '[a] procedural approach to the margin of appreciation ensures that this avenue of democratic legitimation is kept on'. ${ }^{70}$ Viewed in strategic terms, 'arguments based on a European consensus and the procedural approach to the margin of appreciation can be seen as a reaction to critics of the Court's perceived activism and lack of democratic legitimacy., ${ }^{71}$ So how does this work, this 'combined legitimation strategy of the ECtHR, comprising European consensus and a procedural approach to the margin of appreciation', one that far from closing down political discussion 'opens up space for democratic contestation and deliberation. ${ }^{72}$ For Kleinlein, the 'consensus method' is effective because it 'serves the Court to bring its judgments more in line with democratic law-making,' and by doing this effectively, 'it can help to reduce the institutional asymmetry which poses a specific legitimation problem of the ECtHR and other international judicial institutions. ${ }^{, 73}$ It is precisely because 'the democratic premise that judicial law-making can be politically corrected with democratic majorities is hardly respected in international adjudication, ${ }^{74}$ that this powerful regional court with its invasive potential, so far as local legal rules are concerned, needs more than the usual international stand-offishness to the extent that local community feelings are engaged by its rulings. 'The consensus method is a medium through which the ECtHR can signal openness to communication and establish a dialogical node with the Contracting Parties. ${ }^{, 75}$

Recalling Douglas-Scott's yin and yang, Kleinlein observes that '[m]ost commonly, European consensus is applied as a mediator between dynamic interpretation and margin of appreciation. ${ }^{76}$ Under the influence of recent efforts 'to implement a more robust and coherent concept of subsidiarity in conformity with the 'Brighton Declaration on the future of the Strasbourg Court' of April 2012 and Protocol 15', a new 'procedural approach' to the margin of appreciation is arguably 'in the making', one that links the reward of a margin of appreciation to the analysis by the ECtHR 'of whether there are sufficient and effective remedies available at the domestic level. ${ }^{77}$ Furthermore,

the ECtHR concedes a broad margin if the domestic authorities have respected procedural guarantees and balanced the competing interests and fundamental rights diligently. The quality of the parliamentary and judicial review of the necessity of a measure is particularly important. The decision taken by the national authorities must be the outcome of a reasoned decision that has adequately considered and balanced the fundamental rights of the applicant. In this regard, the ECtHR takes account of the degree to which the domestic authorities have based their opinion on studies, impact assessments, or substantial debate. Although the new procedural approach was crucial in a number of cases

\footnotetext{
${ }^{70}$ See the chapter by T. Kleinlein, sec. 1.

${ }^{71}$ See the chapter by T. Kleinlein, sec. 3.1.

72 See the chapter by T. Kleinlein, sec. 1.

${ }^{73}$ See the chapter by T. Kleinlein, sec. 2.1.

${ }^{74}$ See the chapter by T. Kleinlein, sec. 2.1.

${ }^{75}$ See the chapter by T. Kleinlein, sec. 2.1.

${ }^{76}$ See the chapter by T. Kleinlein, sec. 2.2.

${ }^{77}$ See the chapter by T. Kleinlein, sec. 3.1.
} 
even before Brighton, it is generally controversial amongst the judges of the ECtHR. It is a relatively recent innovation, utilised in only a small number of cases and still in need of further development. Yet, it has captured the attention of and gained support from a number of scholars. ${ }^{78}$

Citing the well-known work of theorist John Hart Ely, Kleinlein hones in on how the yin and yang can together produce a satisfactory answer to the right balance conundrum identified above:

Both techniques, consensus-based arguments and the procedural approach to the margin of appreciation, serve to gauge the correct degree of flexibility in the ECtHR's approach, considering that, on the one hand, the Convention should not act as an undue brake on social and economic experimentation, while, on the other, the Court cannot simply follow public opinion because human rights are typically seen as guarantees against the tyranny of the majority. ${ }^{79}$

While it is primarily 'an accommodation strategy', its proper application 'can also have the effect of strengthening domestic political processes, an effect familiar from theories of constitutional adjudication ... Procedural rationality control ensures that an avenue of democratic norm contestation at the national level is open. Furthermore, it provides an incentive for the State Parties to create structures with embedded parliamentary consideration of Convention standards and the ECtHR's judgements. ${ }^{80}$

It is an attractive idea, this thought of assessing the ECHR-sensitivity of a given state practice by reference to how carefully the Convention has been taken into account in the course of its gestation or (if it long predates the Convention) its retention. The reward for including the ECHR in local discussions like this will be a greater likelihood of the margin of appreciation being deployed in a state's favour, but - perhaps now going further than Kleinlein - it should also mean that the state's practices will count in any search for a consensus/emerging consensus in which the ECtHR might choose to engage. To put this another way, a state that has properly grown a human rights culture should be more likely to have its views taken into account in the compilation of a consensus record in a case in which it is not itself involved than one where no such operation of this sort has occurred. Each of these approaches, to margin of appreciation, on the one hand, and consensus, on the other, fits with the move to subsidiarity referred to by Kleinlein and which has been such a feature of recent efforts to renew the ECHR's mission. If we are gloomy, we might see in the rise of far-right and racist parties across Europe an emerging challenge to the very basis of the ECHR, a challenge to its text and original intent of a sort we have not seen since its inception. But if we are happy to imagine a future in which a fundamental challenge like this can be beaten off, then the emphasis here on a rationally-based local engagement with rights is not a bad solution to our effort to use consensus to square the circle between normativity, on the one hand, and on the other, its uneasy bedfellow, democratic will.

\footnotetext{
${ }^{78}$ See the chapter by T. Kleinlein, sec. 3.1.

${ }^{79}$ See the chapter by T. Kleinlein, sec. 3.1.

${ }^{80}$ See the chapter by T. Kleinlein, sec. 4.1.
} 
